\title{
Research on the Development of Personal Finance in Commercial Bank
}

\author{
Fengzhi Dai \\ Harbin university of Commerce in Heilongjiang province China \\ dfz300@163.com
}

\begin{abstract}
Keywords: Personal financial; Financial services; Process research; Commercial Bank; Finance system
\end{abstract}

\begin{abstract}
The rapid growth of Chinese economy and constant accumulation of wealth have brought increasing demand for personal financial service. Commercial banks greatly focus on personal finance in order to improve their competitiveness, which will be the irreversible tendency for the development of commercial banks in the future. It developed gradually in later or middle 1990s to the personal financial services of commercial bank in our country. Personal financing is a well-developed service in foreign commercial banks; however, it is still an emerging and immature service in China.
\end{abstract}

\section{Introduction}

Chinese economic market is fully open to the outside world, foreign banks to enter China's financial market. China's commercial banks will compete with foreign banks on the same terms. However, China's commercial banks in the personal financial management of the current development situation or far from foreign banks. Whether it is financial product development and innovation, management experience and so can not be compared with the development of mature foreign banks. In the domestic personal financial management market, foreign banks to enter the Chinese market with its mature financial products, quality services to seize the quality of our customers resources, domestic and international banking competition is increasing.

\section{Theoretical Summary}

Foreign scholars for the bank personal financial research has been very maturely, the research covers all aspects of personal finance. Mostly from the perspective of financial innovation, the personal financial management of the theoretical basis to be summarized.

Such as Hannon and Mc Dowell from the perspective of technological innovation to explore the motives of financial innovation, put forward the theory of technology. They believe that the adoption of new technologies, especially the development of computers, communications technology and the wide application in the financial industry, provide material and technical assurance for personal finance business, which is the main cause of financial innovation. North and Davies Wallis of the Institutional School argue that financial innovation is a causal change with the economic system, and any changes in the financial system due to institutional reform can be seen as financial innovation. In fact, the institutional school will expand the connotation of financial innovation to include financial business innovation and institutional innovation in two areas, expanding the scope of financial innovation.

At the same time, foreign scholars also from the traditional financial theory and behavioral finance theory, from the individual investment rational and non-complete rational, full information and symmetrical point of view, combined with social characteristics and investment preferences and other factors, personal financial business in-depth Research and analysis.

\section{The Current Situation of Personal Finance in Commercial Banks of China}

China's commercial banks to develop personal financial business began in the late 90s of last century. With the growing awareness of domestic residents financial management, personal wealth 
management business more and more important. In 1996, CITIC opened its first fund management service in Guangzhou Branch. In recent years, the domestic commercial banks have also launched a personal financial services. Outstanding achievements of China Merchants Bank in October 2002 launched for high-end customer financial management of retail financial products and create financial brand "Golden Sunflower". The first to choose a high quality customer resources, to provide a competitive power. Two months after the launch, high-end customers increased by $21 \%$ compared with the introduction, gold sunflower high-end customers accounted for the proportion of the entire retail business transactions more than 60\%. Golden Sunflower financial management has become an important growth point of China Merchants Bank retail financial business.

China's personal financial business development so far, it is not difficult to find that the commercial banks have launched a different brand of financial products, but in the financial content and the role of the product is not much difference, and some even exactly the same. This has to make commercial banks think about how to develop personal finance business in the future.

Although China's commercial personal wealth management business is developing rapidly, but the actual number of users is not much. Most residents are only holding advice and simply for the value-added property can not accept the risk attitude to ask the commercial banks, and financial products do not understand, making the use of very few people.

Commercial banks only provide advisory services, the personal financial business into an extension of the savings function, rather than the real value for the residents of the property, for the fund, stocks, bonds and other aspects rarely involved. Even if there are some products related to bonds, funds, bonds, but in terms of property value can not guarantee. Most of the choice of such financial products, customers only choose a shorter period of investment. Some financial products do not say no way to ensure that the value of funds, and even the risk of loss of the principal, resulting in greater losses. How to improve the credibility of commercial banks has become an important obstacle to the development of personal financial management business banks. If you can not solve the existing problems, personal financial business development will be stagnant.

\section{Improve the personal finance in commercial banks of China}

Commercial banks to issue personal financial products must be low-risk products. According to the customer's different risk appetite, if investors choose a relatively high rate of return of the product, but also to tell investors high returns accompanied by high risk. In the two sides agree with the current financial plan, try to do risk control.

Commercial Banks Strengthen Residents' Financial Awareness. In the personal financial management should be achieved in the preservation and appreciation of customer property, a comprehensive disclosure of the risks in the investment, improve bank credibility. China Banking Regulatory Commission promulgated on strengthening the bank personal finance business investment management notice clearly stipulates that commercial banks to customers committed guarantee rate of return shall not be higher than the same period savings deposit interest rates. Therefore, the banks in the personal financial management business should be to explain the risks of investment, do not deceive customers. In the course of the sale of financial products, commercial banks should clearly inform the customer of this individual financial products required funds, management, investment direction, etc., in each time the commercial banks should also inform the customer funds investment situation and income situation. Commercial banks should also really establish an effective financial product risk control monitoring system. And inform the customer to protect the legitimate rights and interests of investors. At the same time, the need to give full play to the role of industry associations, the establishment of a unified information disclosure system. Fair, just and open to carry out personal wealth management business.

Investors in the choice of bank personal wealth management business should also take the initiative to understand the situation, the bank asked the product required credit, management, investment direction, risk and so on. According to their own risk tolerance, choose their own financial products, do not blindly profitable yield and ignore the high risk of high returns. After choosing a good bank and a suitable financial product, you should not go to the bank management and should regularly understand the investment trend, state and direction. Reasonable arrangements 
for funds, get the maximum benefit.

Develop Characteristic Business to Enhance Product Innovation. Product development innovation is the key to the survival of a personal wealth management business. First of all, the existing financial products on the market analysis, and grasp the market trend, ahead of the future forecast of personal financial products demand. Second, each customer's risk tolerance is different, the demand for personal financial products is not the same, it should be based on different customers to develop personalized products, to provide personalized service, so that innovative products more targeted to improve the efficiency of innovation.

Commercial banks through the analysis of the market, to ensure that new innovative products in the market acceptance is low, with a broad customer market, thereby reducing the cost of innovation and improve product returns. In the control of the product to strengthen the function at the same time also strengthen the development. Follow the market changes, according to the different needs of customers, the combination of financial management.

Strengthen the Training of Financial Professionals. Commercial banks should learn from the advanced management experience of foreign commercial banks to develop mature personal financial management business. First of all to improve the senior management of China's commercial banks. And then according to the needs of the market and customers, cultivate a group of comprehensive knowledge of financial advisers. Pay attention to cultivate financial management personnel to improve the financial management of financial products and understanding of the degree. Fully understand the customer's risk appetite and financial situation, to develop a personalized customer-friendly personal financial solutions. Training a group of rich personal financial experience can be independent for customers to develop and personal financial management of high-quality personnel, to understand a wide range of knowledge to help customers effectively avoid risks, to achieve asset value. Commercial banks can carry out the performance system of individual financial management personnel, strengthen the enthusiasm of financial management personnel.

In the selection of personal financial management practitioners should be a clear standard. Selection of strong, comprehensive high quality, strong learning ability. Through professional training, to develop a thorough understanding of financial products and investment market knowledge, at the same time have good communication skills and marketing knowledge of high-quality financial management personnel. In the introduction of personal financial products to clear their responsibilities, improve service levels. To introduce international experience and access to service standards and concepts, establish and improve the financial management practitioners self-discipline of industry standards, professional ethics. To create a set of China's national conditions in line with the personal financial management personnel qualification system.

\section{References}

[1] Keenan. Sticky Solution[J]. Personal Financial Management U.S.2014(3):8-9

[2] Brigham. Fundamental of Financial Management[J]. Higher Education Press.2015(5):13-17

[3] Eric Tyson. Financial Management And Investing[J]. Machinery Industry Press.2016(4):14-16

[4] Scandlyn. Personal Financial Management[J]. Chartered Accountants Joumal.2013(6):23-24

[5] Shaw, E.Financial Deeping in Economic Development[J].Oxford University Press, 2011(4): 89-109.

[6] King, R.G., and Ross, L. Finance and Growth: Schumpter Might Be Right[J].Quarterly Journal of Economics, 2012(8): 717-738.

[7] Greenwood, J., and Jovanovic, B.Financial Development, Growth, and the Distribution of Income[J], Journal of Political Economy2013(5): 1076-1107.

[8] Aghion, P., Bolton, P. A theory of trickle-down growth and development[J].Review of Economics Studies, 2014(2): .151-172.

[9] Townsend, R.M., and Kenichi, U. Financial Deepening Inequality and Growth A Model-Based Quantitative Evaluation MF Working Paper 2013(3): 193-194. 
[10]Bourguignon, F., and Verdier, T.Oligarchy, democracy, inequality anf growth[J].Journal of Development Economics, 2010(2): 285-313. 